\title{
TC-GLUTATHIONE COMPLEX (Tc -GSH) : LABELLING, CHEMICAL CHARACTERIZATION AND BIODISTRIBUTION IN RATS
}

\author{
K. Baba*1, J. L. Moretti ${ }^{1}$, P. Weinmann ${ }^{1}$, \\ R. Senekowitsch-Schmidtke ${ }^{2}$ and M. T. Ercan ${ }^{3}$ \\ 1 Université Paris Nord, Laboratoire de Biophysique Expérimentale et Radiopharmacologie, \\ UPRES 2360, UFR Santé Médecine Biologie Humaine, 74, rue M. Cachin, \\ 93018 Bobigny cedex, France \\ 2 Nuklearmedizinische Klinik und Poliklinik, Ismaninger Strabe 22, \\ D-81675 München, Germany \\ 3 Hacettepe University, Medical Center, Ankara, Turkey
}

\begin{abstract}
The chemical structure of $99 \mathrm{mTC}$-GSH has been estabilished using the ${ }^{99} \mathrm{Tc}$ isotope. Labeling of glutathione with technetium in the presence of stanous chloride gave a high yield result. In a comparative study between ${ }^{99} \mathrm{Tc}$ and $99 \mathrm{mTc}$ glutathione, the Tc-GSH complex obtained was purified and characterized by uv, visible spectroscopy, HPLC, Biogel chromatography, mass and NMR spectroscopy. Stoichiometric analysis showed a $2: 1$ molar ratio of GSH/Tc for the reaction. The molecular mass assessed by mass spectroscopy was $727 \mathrm{Da}$ corresponding to an oxo(bis) glutathione technetate. NMR studies demonstrated that each glutathione molecule was coordinated to technetium via cysteinyl sulfur and nitrogen atoms. The biodistribution of the complex was studied in normal rats. Blood clearance was rapid during the first hour involving a biexponential curve $\left(t_{1 / 2}(1): 50 \mathrm{~min}, t_{1 / 2}(2): 400 \mathrm{~min}\right)$. No radioactive accumulation was found in any specific organ except kidney and bladder. All the activity excreted was found unchanged in urine. In conclusion, Tc-GSH displayed an anionic dimer form as GSH-Tc-GSH. We assume that the complex is a tetradentate $(2 \mathrm{~N}, 2 \mathrm{~S})$ complex containing a pentavalent technetium coordinated by two thiol and nitrogen atoms of both GSH ligands, and an apical oxo group.
\end{abstract}

\section{INTRODUCTION}

During the recent years increasing fundamental research about the structure of Tc radiopharmaceuticals has been done using the long-lived ${ }^{99} \mathrm{Tc}$ isotope $\left(\mathrm{t}_{1 / 2}=2,13.10^{5} \mathrm{yr}\right)$. When using ${ }^{99} \mathrm{Tc}$, one must bear in mind that the complex formations of ${ }^{99} \mathrm{Tc}$ and $99 \mathrm{mTc}$ may be different, resulting from the different concentration ranges used for the two isotopes $(1,2)$ Several investigators (3-7) have used $99 \mathrm{mTc}$-labeled sulfhydryl containing aminoacids, carbonic acids and heterocyclic compounds as a new approach in radiopharmaceutical design. It was demonstrated that small molecular weight complexes of $99 \mathrm{mTc}$ with fast renal clearance or biliary excretion and no significant uptake by any other organs showed sufficient accumulation in tumors for early scintigraphic visualization (8-10). The renal route of excretion is an advantage over the biliary one, especially for the identification of abdominal lesions $(9,11)$. This point was also emphasized by Fischman(11) with the use of chemotactic peptides. Peptides of low molecular weight labeled with $99 \mathrm{mT}$ c could be a better alternative because of their faster blood clearance and excretion mainly via the kidney. Detailed structural information concerning Tc-radiopharmaceuticals is now available for Tc-AHBDP (12), Tc-glucoheptonate (13) and oxotechnetium compounds (14). Glutathione $\gamma$ glutamyl cysteinyl glycine was chosen as a model compound because of the critical fonctions it carried in humans (15). Due to its a small molecular weight, it was expected to better penetrate injured capillaries in inflammatory lesions (16), breast cancer (17), head and neck tumors(18).

More detailed structural information about the radiopharmaceuticals in use today would greatly facilitate the prediction of the in vivo stability and target-organ distribution. For this reason the study of the Tc-GSH chemical structure and its biodistribution in rats were undertaken.

\section{MATERIAL AND METHODS}

Glutathione (reduced form), $\mathrm{SnCl}_{2}$, and buffer products were purchased from Sigma Aldrich. $\mathrm{Na}^{99} \mathrm{mTCO}_{4}$ was eluted from a commercial ${ }^{99} \mathrm{Mo} / 99 \mathrm{mTc}$ generator (Cis Biolnternational). $\mathrm{NH}_{4}{ }^{99} \mathrm{TcO}_{4}$ was obtained from Dupont-NEN laboratories.

Labeling reaction of the Tc-GSH complex was performed with $20 \mathrm{mg}$ of glutathione dissolved in $2 \mathrm{ml}$ phosphate buffer while stirring and $0,3 \mathrm{ml}$ of $\mathrm{SnCl}_{2} \cdot 2 \mathrm{H}_{2} \mathrm{O}(1 \mathrm{mg} / \mathrm{ml}$ of $\mathrm{HCl} 0,05 \mathrm{~N})$ was added. The mixture was stirred for a few minutes and filtered. $2 \mathrm{ml}$ of pertechnetate were added and the mixture was shaken for few seconds and left to react for $15 \mathrm{~min}$ at room temperature. 
The radiochemical purity of the TC-GSH complex was assessed by ITLC using a CHROMELUC Nu-102 radiochromatogram (Numelec) with silica-gel plates and two solvents : Butanone and $\mathrm{NaCl}$.

Electrophoretic experiments of the Tc-GSH complex were performed on cellulose acetate strips in phosphate buffer $(0.05 \mathrm{M}, \mathrm{pH} 7) .5 \mu \mathrm{l}$ of each solution were placed at midpoint of the band and $200 \mathrm{~V}$ was applied for $1 \mathrm{~h}$ at room temperature. After drying, each strip was cut into equal lenght and the activity counted with a $B$ counter (Beckman, LS 6000SC) for the ${ }^{99} \mathrm{Tc}-\mathrm{GSH}$ complex and $\gamma$ counter (Wallac, LKB1261).

Ultraviolet and visible electron spectra of the Tc-GSH complex were recorded between 190 and $850 \mathrm{~nm}$ on a HEWLETT PACKARD 8452 spectrophotometer using closed 10-mm Supracil quartz cuvettes.

Infrared spectra of the Tc-GSH complex were recorded from $600-4000 \mathrm{~cm}^{-1}$. Spectra were performed on solid samples prepared as $\mathrm{KBr}$ pellets.

An analytical study of the 99mTC-GSH complex was determined by gradient HPLC (C-18 reversed phase uptisphere $5 \mu \mathrm{m}$ UP50DB-25K, Interchim) using a flow rate of $1 \mathrm{ml} / \mathrm{mn}$ equiped with a UV-Vis detector and gamma-counting system ( $\mathrm{Nal}$ crystal ) coupled to two channel analysers and

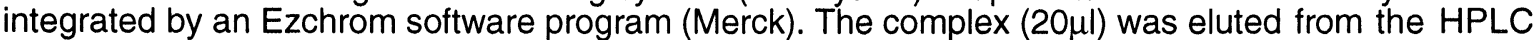
column with a gradient medium of $(A) 0,05 \mathrm{M}$ phosphate buffer $\mathrm{pH}=7$ and $(B) 30 \%$ ethanol in (A).

Gel chromatography of the Tc-GSH complex was performed on biogel P2 columns (Biorad) with the technique introduced by Persson (19). The biogel P2 was used to separate and identify smaller molecular weight compounds. The various samples were eluted with PBS $(\mathrm{pH}=7)$ and the column was calibrated for different molecular weight ranges.

NMR analysis of the GSH and the Tc-GSH complex were obtained at $20^{\circ} \mathrm{C}$ with a Varian NMR spectrometer at $500 \mathrm{MHz}$.

Fast atom bombardement mass spectroscopy (FAB+ - MS) of the Tc-GSH complex were recorded with a MAT 95 spectrometer by mixing $1 \mu \mathrm{l}$ sample with $5 \mu \mathrm{l}$ glycerol and bombardement with caesium atoms of low energy of about $150 \mathrm{eV}$ at room temperature.

Blood clearance of $99 \mathrm{mTC}-G S H$ complex was studied in male sprague dawley rats $(150-200 \mathrm{~g})$. $100 \mu \mathrm{l}$ of $99 \mathrm{mTc}-\mathrm{GSH}$ were injected i.v. and blood samples drawn from a femoral vein at $5 \mathrm{~min}, 2 \mathrm{~h}$, $4 \mathrm{~h}, 6 \mathrm{~h}$ and $24 \mathrm{~h}$. The samples were counted in a gamma-counter. The means of percentage injected dose were plotted with the course of time.

The in vivo distribution studies were performed in male sprague dawley rats $(150-200 \mathrm{~g})$ by injecting into the femoral vein $100 \mathrm{ml}$ of $99 \mathrm{mTC}$-GSH. Five rats were studied for each data point. The rats were killed and dissected at $1 \mathrm{~h}, 6 \mathrm{~h}$ postinjection. All the organs were removed, samples of blood and urine were also obtained. The organ samples were weighted and counted in a gammacounter ( Wallac, LKB1261)).

\section{RESULTS}

The TC-GSH complex displayed a negative charge on paper electrophoresis. Instant thin layer chromatography analysis results are summarized in table I. In general, free pertechnetate moved to the solvent front whereas reduced $99 \mathrm{mTc}$ and bound $99 \mathrm{mTc}-\mathrm{R}(\mathrm{R}-\mathrm{Tc}$ ) remained at the spot of origin in the butanone solvent. In the saline solvent, reduced $99 \mathrm{mTc}$ stayed at the origin whereas the free pertechnetate and R-Tc moved with the solvent front. The labeling yield of $99 \mathrm{mTc}-\mathrm{GSH}$ detected by paper and thin layer chromatography was over $95 \%$. The UV visible spectra of Tc-GSH complex showed an absorbance band at $385 \mathrm{~nm}$ (fig.1). Glutathione alone and glutathione-Sn did not absorb at $385 \mathrm{~nm}$. The ${ }^{99} \mathrm{Tc}-\mathrm{GSH}$ complex was stable for more one week at room temperature. The stoechiometry for the reaction of Tc with glutathione determined at partial molar ratios at different glutathione concentrations $(\mathrm{Sn} / \mathrm{Tc} / \mathrm{GSH}=1 / 1 / \mathrm{X}, \mathrm{X}=0-10$ ) indicated the existence of two GSH coordinated with one Tc ion (fig. 2).

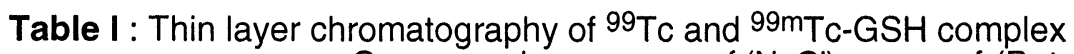

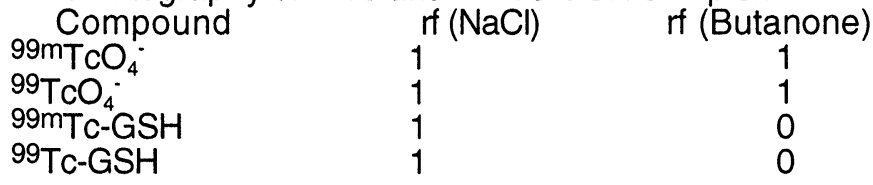

The IR spectrum of the Tc-GSH complex showed the absence of the $2540 \mathrm{~cm}^{-1}$ band and the presence of the vibration band of the $\mathrm{TC}=\mathrm{O}$ core $\left(931 \mathrm{~cm}^{-1}\right)$. 
Figure 1 : UV-Vis spectra of various compounds at $25^{\circ} \mathrm{C}$

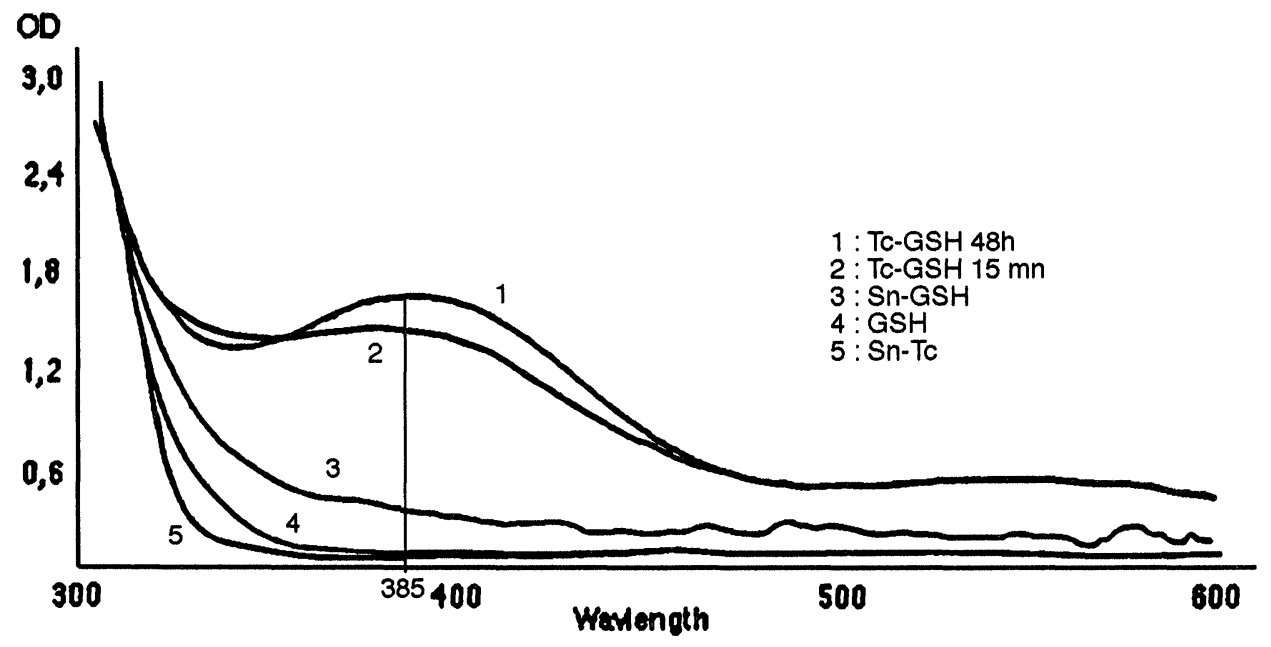

Figure 2 : Mol-ratio reaction curve of technetium with gluthatione at $385 \mathrm{~nm}$

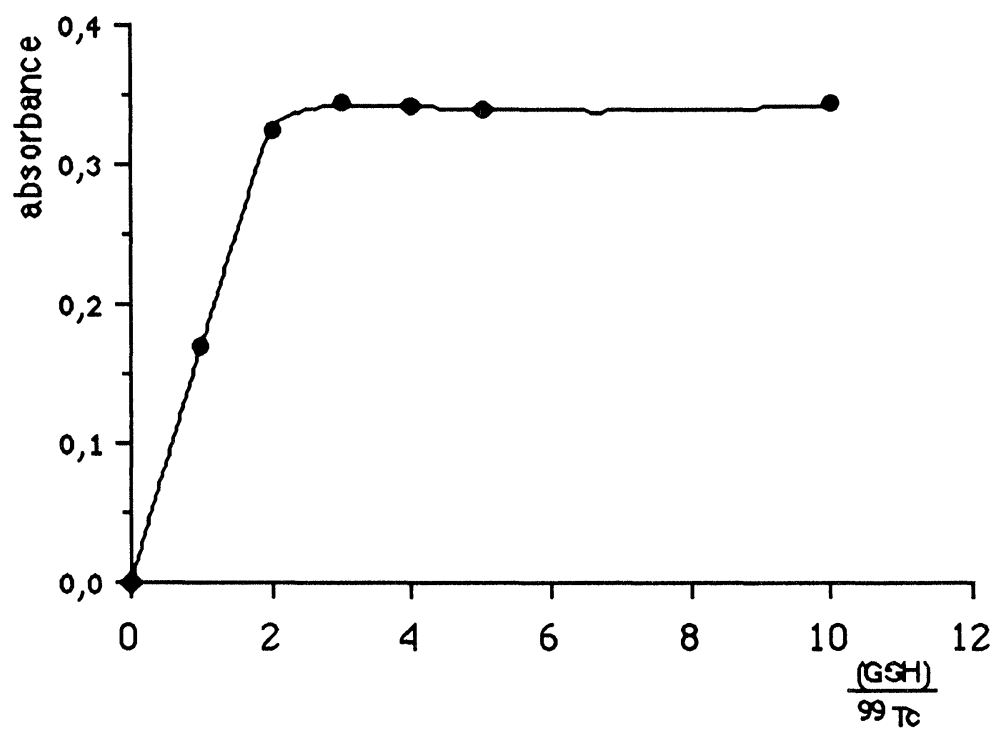

Table II : Proton NMR spectroscopic data of GSH and ${ }^{99} \mathrm{Tc}$-GSH complex

\begin{tabular}{|c|c|c|c|c|c|c|}
\hline $\begin{array}{c}\text { Compound } \\
\text { GSH }\end{array}$ & $\begin{array}{c}\text { cys } \\
\delta\left(\mathrm{C}_{\alpha} \mathrm{H}_{2}\right) \\
3,794 \\
3,807 \\
3,820\end{array}$ & $\begin{array}{c}\text { cys } \\
\delta\left(\mathrm{C}_{\beta} \mathrm{H}_{2}\right) \\
2,917 \\
2,929 \\
2,936\end{array}$ & $\begin{array}{c}\text { gly } \\
\delta\left(\mathrm{C}_{\alpha} \mathrm{H}_{2}\right) \\
3,943 \\
3,953\end{array}$ & $\begin{array}{c}\text { glu } \\
\delta\left(\mathrm{C}_{\alpha} \mathrm{H}_{2}\right) \\
4,539 \\
4,550\end{array}$ & $\begin{array}{c}\text { glu } \\
\delta\left(\mathrm{C}_{\beta} \mathrm{H}_{2}\right) \\
2,122 \\
2,137 \\
2,150\end{array}$ & $\begin{array}{c}\text { glu } \\
\delta\left(\mathrm{C}_{\gamma} \mathrm{H}_{2}\right) \\
2,507 \\
2,521 \\
2,537\end{array}$ \\
\hline Tc-GSH & $\begin{array}{l}3,767 \\
3,779\end{array}$ & $\begin{array}{l}2,956 \\
2,971\end{array}$ & $\begin{array}{l}3,791 \\
3,813\end{array}$ & $\begin{array}{l}4,550 \\
4,563\end{array}$ & $\begin{array}{l}2,100 \\
2,158 \\
2,170 \\
2,185 \\
2,199\end{array}$ & $\begin{array}{l}2,558 \\
2,573 \\
2,583 \\
2,597\end{array}$ \\
\hline
\end{tabular}

The NMR spectrum of the GSH and the Tc-GSH complex demonstrated the disappearance of fine structure of the signal (fig. 3). The proton signal (table II) indicated, in particular, that protons bound to cysteinyl $\alpha$ and $\beta$ carbons appeared to be altered. 
Figure $3:{ }^{1} \mathrm{H}$ NMR spectra of GSH (A) and ${ }^{99} \mathrm{TC}-\mathrm{GSH}$ complex (B) at $500 \mathrm{MHz}, 20^{\circ} \mathrm{C}$

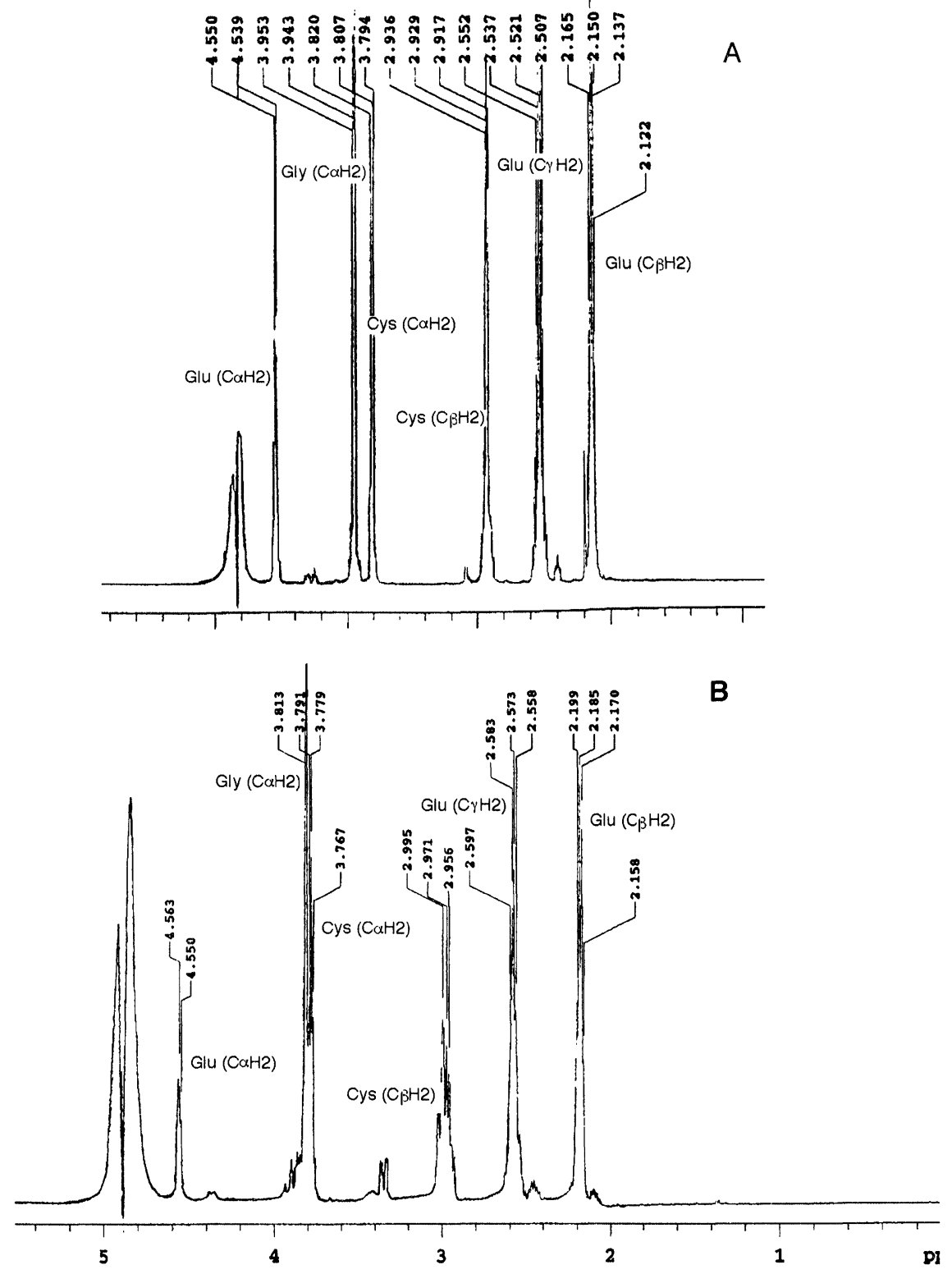

The ${ }^{99} \mathrm{Tc}-\mathrm{GSH}$ complex, analyzed by fast atom bombardement mass spectroscopy, showed a molecular mass between $683 \mathrm{Da}$ and $726 \mathrm{Da}$. This mass corresponded to a GSH-Tc-GSH chelate complex. This complex containing a tetra or a pentavalent technetium coordinated by two thiol and nitrogen atoms of two GSH ligand and an apical oxo group (fig. 4).

HPLC radiochromatograms of the 99mTc-GSH complex exhibit a single peak with a retention time of $12 \mathrm{~min}$, the retention time of free $99 \mathrm{mTCO}_{4}{ }^{-}$being equal to $6 \mathrm{~min}$.

The radiochromatogram of the $99 \mathrm{mTC}$-GSH obtained by analysis on the biogel P2 column demonstrated that all the radioactivity was present in a single peak with an elution volume of $16 \mathrm{ml}$.

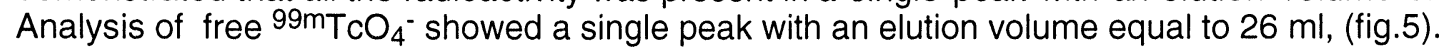


Figure 4 : Structure of GSH-TC-GSH complex

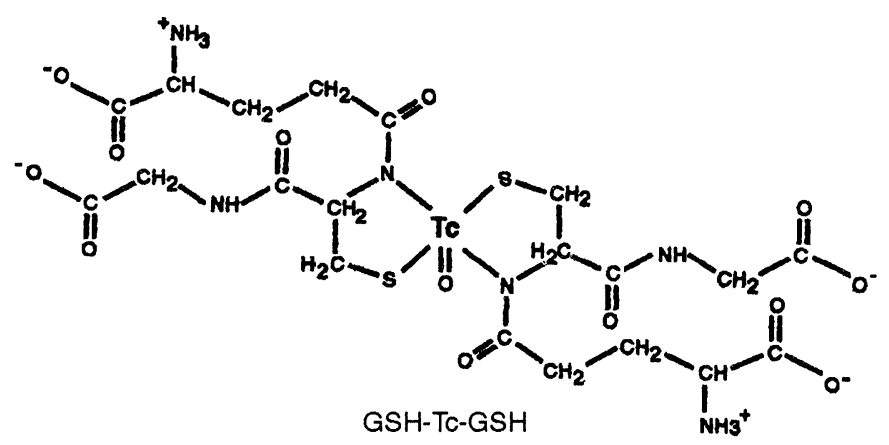

Table III : Biodistribution of $99 \mathrm{mTC}-\mathrm{GSH}$ complex in normal sprague dawley rats $(n=5)$

\begin{tabular}{lll} 
organ & \multicolumn{1}{c}{ \%dose/g } & \multicolumn{1}{c}{$6 \mathrm{~h}$} \\
kidneys & $17,5 \pm 3$ & $19,7 \pm 3$ \\
urine & $52 \pm 9$ & $69 \pm 11$ \\
blood & $5,3 \pm 0,6$ & $2,3 \pm 0,23$ \\
liver & $4,2 \pm 0,5$ & $2,6 \pm 0,23$ \\
heart & $2,5 \pm 2,3$ & $2,3 \pm 0,23$ \\
spleen & $2,17 \pm 0,15$ & $2,2 \pm 0,15$ \\
lung & $1,4 \pm 0,12$ & $1,1 \pm 0,12$
\end{tabular}

Figure 5 : radiochromatogram of Tc-GSH complex obtained by biogel P2 chromatography

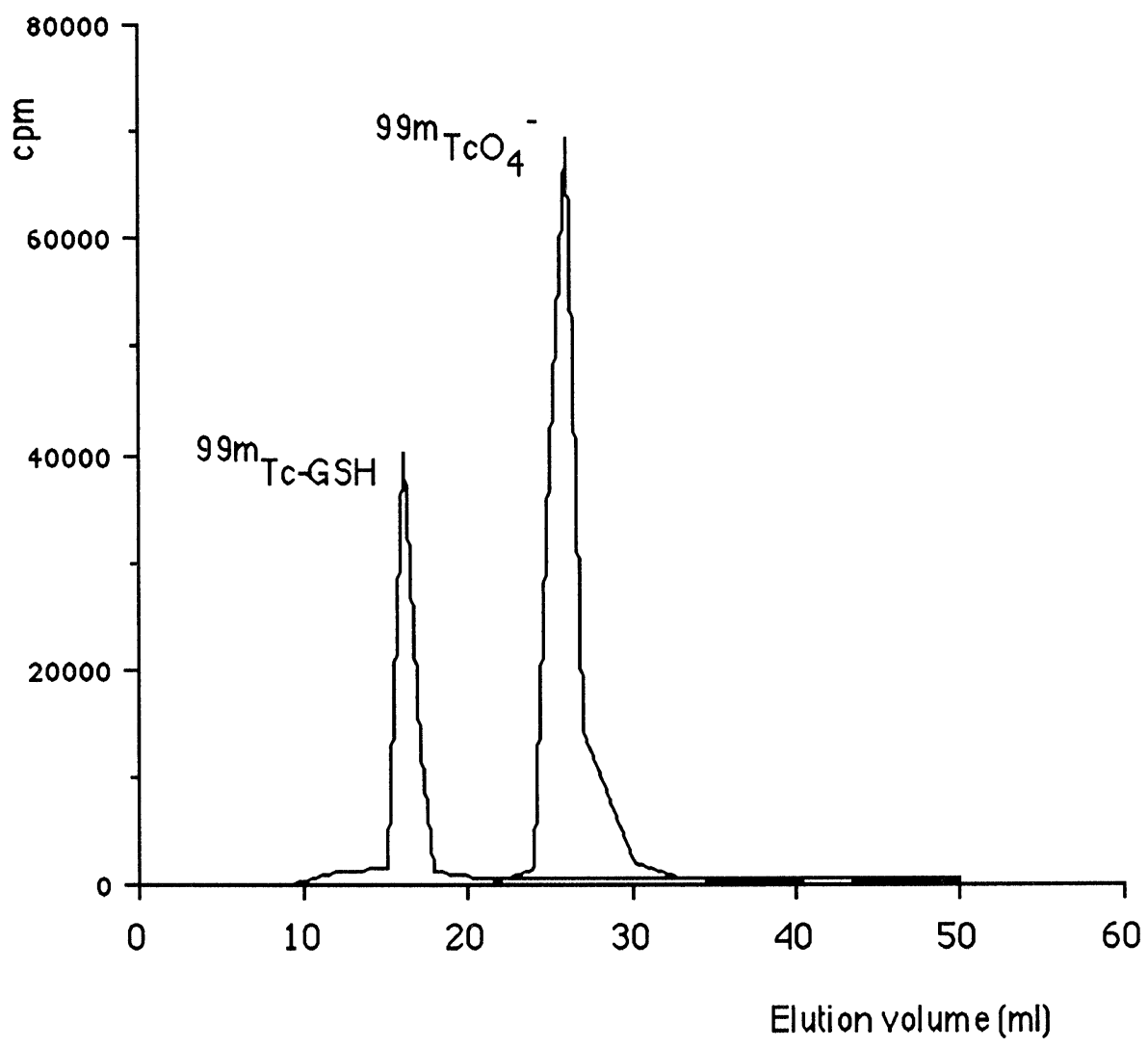


Figure 6 : Blood clearance of ${ }^{99 m}$ Tc-GSH complex in male sprague dawley rats $(n=5)$

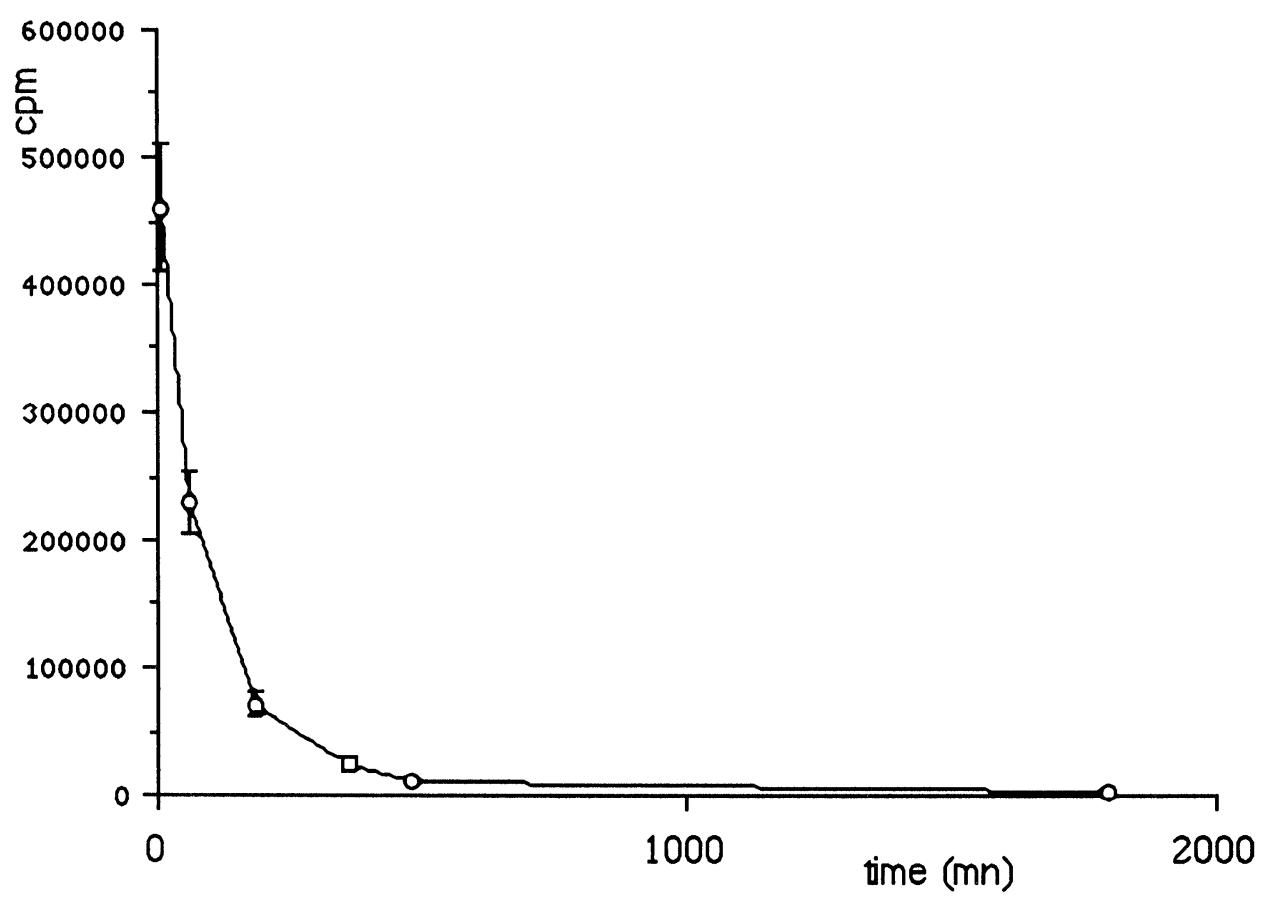

Figure 7 : Biodistribution of $99 \mathrm{mTC}-\mathrm{GSH}$ complex in normal sprague dawley rats $(n=5)$

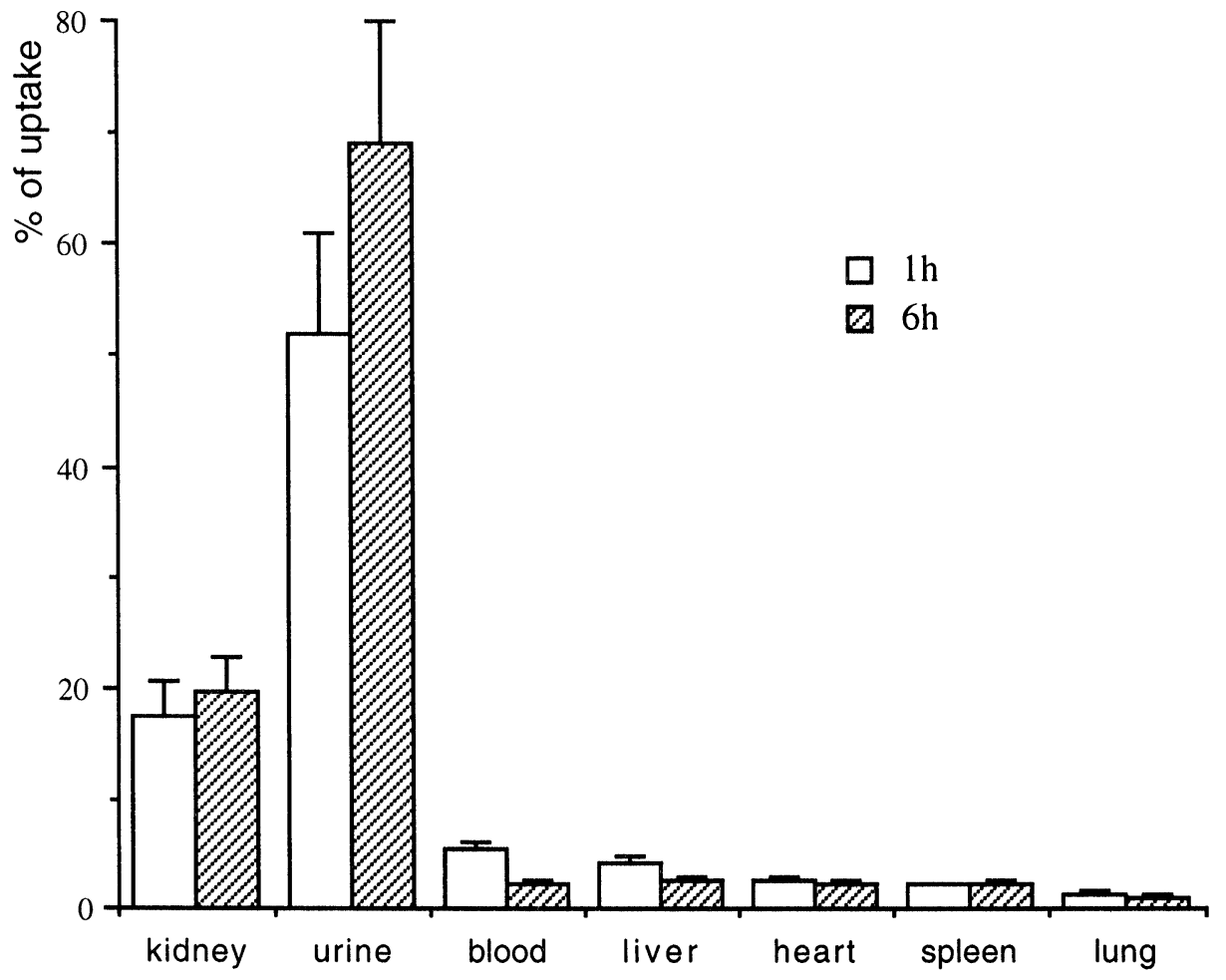


The blood clearance of $99 \mathrm{mTc}-\mathrm{GSH}$ complex in rats is shown on (fig. 6). The deconvolution of this curve demonstrated a rapid component $(T 1 / 2(1)=50 \mathrm{~min}, \mathrm{~T} 1 / 2(2)=400 \mathrm{~min})$.

The biodistribution of $99 \mathrm{mTC}-\mathrm{GSH}$ complex is given in (table III). All organs showed low uptake values except kidneys. The elimination occured via the kidneys as indicated by high radioactivity levels in urine samples (fig. 7).

\section{DISCUSSION}

In the present study, labeling of glutathione with $99 \mathrm{mTc}$ using stanous chloride as reducing agent gave a dimer complex with a high radiochemical yield, over $95 \%$ detected by thin layer chromatography

The NMR spectrum of the Tc-GSH complex indicated that the protons bound to cysteinyl $\alpha$ and $B$ carbons appeared to be modified, suggesting an effect of the central $T c=0$ core in the molecule.

Glutathione GSH could fulfill the fonction of a reducing agent and of a ligand for ${ }^{99 \mathrm{~m}_{\mathrm{TCO}}}{ }^{-}$. The complexation rate seems to be higher than the reduction, since no ligand free $\mathrm{Tc}(\mathrm{V})$ compound was formed. The reduction rate diminished by decreasing the concentration of the $\mathrm{GSH}$, which offers the possibility of determining the oxydation state in the complex by Sn(II) titration $(20,21)$

Some properties of the 99mTc-GSH complex have already been reported (18). A highly watersoluble complex with a negative charge was formed. Blood clearance studies indicated a fast decline of radioactivity during the first hour after administration.

According to Despopoulos theory (19), an agent could be secreted through the renal tubles if it possesses anionic properties and bonding capability wich are expressed through the -CO-NH$\left(\mathrm{CH}_{2}\right)-\mathrm{COOH}$ sequence. The biodistribution of the anion 99mTc-GSH complex with the carbonyl amide sequence showed that the target organ was the kidney with a fast elimination by filtration.

Glutathione plays a critical role in the detoxification reactions by reducing $\mathrm{H}_{2} \mathrm{O}_{2}(15,24)$. There is increased demand for GSH in the injured and cancerous cells (23-26) and possible retention. Although the thiol group responsible for such detoxification reactions was utilized for $99 \mathrm{mTc}$ binding in the 99mTc-GSH complex $(27,28)$. GSH might be still be biologically active.

$99 \mathrm{mTC}-\mathrm{GSH}$ complex is a small molecule which diffuses back from inflammatory and cancerous lesions into the blood very easily $(6,9,17)$. This intracellular concentration might be due to the transfer of $99 \mathrm{mTc}$ to another ligand inside the cell allowing concentration.(29,30).

\section{ACKNOWLEDGEMENTS}

This work was supported by grants from the Cancer ligues dép:89 and 93. The authors thank: laboratoire de chimie, Y.Leroux, D. El Manouni and G. Leger for recording NMR spectra. F. Benazzouz for helpful experiments and G.Baillet for paper reviewing

GSH : glutathione, Tc : technetium, $\mathrm{SnCl}_{2}$ : stanous chloride, cys : cysteine, gly : glycine, glu : glutamic acid, $\mathrm{TcO}_{4}:$ pertechnetate ion

\section{REFERENCES}

1) Jones A.G. and Davison A. Int. J. Appl. Radiat. Isot. 1982; 33:867-874

2) Eclman W.C., Meinken G. and Richard P. J. Nucl. Med. 1972; 13:577-58

3) Tubis M., Endow J.S. Int. J. Appl. Radiat. Isot. 1968; 19:835-840

4) Tubis M., Krishnamurthy G.T., Endow J.S. and Blahd W.H. J. Nucl. Med. 1972; 13:652-654

5) Lin T.H., Khentigan A., Winchell H.S. J. Nucl. Med. 1974; 15:34-35

6) Hagan P.I., Ayres P.R., Halpin S.E. and Chauncey D.M. J. Nucl. Med. 1975; 16:531-532

7) Inoue O., Ikeda I., Kuruta K. Radioisotopes. 1976; 25:23-30

8) Roizenblatt J., Buchpiguel C.A., Menguetti J.C., Caldeira J.A. and Camargo E.E. Eur. J. Nucl. Med. 1991; 18:955-958

9) Ercan M.T., Aras T., Ünlenen E., Ünlü M., Ünsal I., Hasçelik Z. Nucl. Med. Biol. 1993; 20:881-887 10) Ercan M.T., Bekdik C.F., Sarizi T. Int. J. Appl. Radiol. Isot. 1978; 29:697-698

11) Fischman A.J., Pike M.C.., Kroon D., Fucello A.C., Rexinger D., Tenkate C., Wilkinson R., Rubin R.H. and Strauss H.W. J. Nucl. Med. 1991; 32:483-991

12) Mankhetrkon S., Blanchot C., Duran-Cordobes M., EIManouni D., LerouxY. And Moretti J.L. Metal Based Drug 1995; 2 (14):201-210

13) de Kieviet W. J. Nucl. Med. 1981; 22:7.3-709

14) Hansen L, Marzilli L.G. and Taylor A. Q. J. Nucl. Med. 1998; 42:280-293

15) Kapiowitz N., Aw T.Y., Ookhtens M. Ann. Rev. Pharmacol. Toxicol. 1985; 25:715-744 
16) Hosain F., Haddon M.J., Hosain H., Drost J. and Spencer R.P. Nucl. Med. Biol. 1990; 17:151155

17) Duman Y., Bilkay Ü., Teber E., Yüksel D., Erdem S., Argon M., Yilmaz R. and Özbal O. Eur. J. Nucl. Med. 1996; $19: 1097-10$

18) Ercan M.T., Aras T., Aktas T., Ünlenen E., Mocan G. and Bekdik R.P. Nucl. Med., 1994, 33 :224-228

19) Despopoulos A. J., J. Thero. Biol., 1965, $8: 163-192$

20) Person B.R.P.and Darte L. J. Chromatogr. 1974; 101:315-326

21) Steigman J., Meinken G., Richards P. Int. J. Appl. Radiat. Isot. 1975; 26:601-609

22) Ecklman W.C., Meinken G., Richards P. J. Nucl. Med. 1972; 13:577-581

23) Bernard B.F., Krenning E.P., Breeman W.A.P., Rolleman E.J., Bakker W.H., Visser T.J., Mäkke $H$. and de Jong M. J. Nucl. Med. 1997; 38:29-1933

24) Meister A., Anderson M.E. Ann.Rev. Biochem. 1983; 52:417-423

25) Reed D.J. Ann. Rev. Pharmacol. Toxicol. 1990, 30:603-631

26) Dalhoff K., Ranek L., Mantoni M. and Poulsen H.E. Liver.1992; 1:341-343

27) Suess E., Malessa K., Ungersböck, Kitz P., Podreka I., Heimberger K., Hornykiewicz O. and Deecke L. J. Nucl. Med., 1991; 32:1675-1681

28) Muenze R. : Technetium-99m radiopharmaceuticals : structure-activity relationships. In : Deckart H, Cox PH eds. Principales of radiopharmacology. Dordrecht: Martinus Nijhoff, 1987:100-116

29) Xue L.Y., Noujaim A.A., Sykes T.R., Woo T.R. and Peng Z. Q. J. Nucl. Med. 1996; 40:341-350

30) Syhre R., Seifert S., Spies H., Gupta A. and Johannsen B. Eur. J. Nucl. Med. 1998; 25:793796

Received: June 8, 1999 - Accepted: June 25, 1999 Received in revised camera-ready format: August 23, 1999 